Yönetim ve Ekonomi Araștırmaları Dergisi / Journal of Management and Economics Research

Cilt/Volume: $14 \quad$ Sayı/Issue: $4 \quad$ Eylül/September $2016 \quad$ Doi: http://dx.doi.org/10.11611/yead.282052

\title{
COMPARISON OF INTERNATIONAL AND DOMESTIC ACQUISITIONS: A LITERATURE REVIEW
}

\author{
Asist. Prof. Dr. Ömer Faruk Genç ${ }^{\star}$
}

\begin{abstract}
International Aquisitions (IAs) have been used extensively by companies. Although IAsdiffer from domestic aquisitions, there is not a literature review about how they differ. A literature review of acquisitions in terms of comparison between international and domestic deals is provided in this study. Based on the literature, it was shown that international acquisitions differ significantly from domestic acquisitions in terms of motivations, outcomes, success factors, integration problems, information asymmetry, and diversification. The study also identifies new aveanues for acquisition researh. The acquisition paradox and motivation-outcome inconsistency are identified as major issues in acquisition research, and ways to deal with these issues including using benchmarking methodology, risk-adjusted returns, and examining motivations in different ways are provided. In addition, acquisitions by emerging market multinationals and private companies, acquisitions of state-owned enterprises, pre-announcement and negotiation stages are identified as understudied areas with great potential in acquisition research.
\end{abstract}

Keywords: Acquisitions, mergers, literature review, international acquisitions.

JEL Code:M10, M16, M19

\section{ULUSLARARASI VE ULUSAL ŞİRKET SATIN ALIMLARININ KARŞILAŞTIRILMASI: LITERATÜR ÖZETİ VE GELECEĞE DÖNÜK ÖNGÖRÜLER}

\section{ÖZET}

Uluslararası şirket satın alımları son yıllarda oldukça sık kullanılmakta olmasına ragmen, bu şirket satın alımlarının ulusal şirket satın alımlarından nasıl farklılaştığ hakkında bir literatür taraması bulunmamaktadır. Bu çalışmada, ulusal ve uluslararası şirket satın alımlarının karşılaştırılması hakkında detaylı bir literatür taraması yapılmaktadır. Bu literatür taramasına dayanılarak, ulusal ve uluslararası şirket satın alımlarının satın almanın motivasyonları, sonuçları, başarı faktörleri, entegrasyon sorunları, bilgi asimetrisi ve çeşitlendirme açılarından farklılık arz ettikleri gösterilmiştir. Çalışma ayrıca, şirket satın alma konusundaki araştırmalar için yeni perspektifler sunmaktadır. Şirket satın alma paradoksu ve

\footnotetext{
*Abdullah Gul University, School of Leadership and Management, Department of Business Administration, omer.genc@agu.edu.tr
} 
Yönetim ve Ekonomi Araștırmaları Dergisi / Journal of Management and Economics Research

Cilt/Volume: $14 \quad$ Sayı/Issue: $4 \quad$ Eylül/September $2016 \quad$ Doi: http://dx.doi.org/10.11611/yead.282052

motivasyon-sonuç tutarsızlı̆̆ literatürdeki bazı sorunlar olarak belirlenmiş olup, kıyaslama metodolojisi, riske uyarlanmış performans kriterleri ve şirket satın alımlarının motivasyonlarının farklı şekilde ele alınması gibi öneriler sunulmuştur. Bunlara ek olarak, gelişmekte olan ülkeler ve özel şirketler tarafindan yapılan şirket satın alımları, kamu iktisadi teşebbüslerinin satılmaları, şirket satın alımlarının duyuru öncesi öndeki pazarlık süreci az çalışılmış alanlar olarak belirlenmiş ve bu alandaki araştırmacıların dikkatlerine sunulmuştur.

AnahtarSözcükler: Uluslararası ve Ulusal Şirket Satın Alımları, Literatür Taraması.

\section{INTRODUCTION}

There are multiple ways to grow a company. One option is to purchase another corporation. This process is better known as an acquisition. Mergers and Acquisitions (hereafter referred to simply as acquisitions) have become one of the most popular ways to grow today.Thousands of companies engage in acquisitions and spend billions of dollars each year. The number and value of acquisitions peaked in 2007 (UNCTAD, 2008). In that year, there were more than 45,000 transactions, with a total value of approximately 5.5 trillion US dollars. The total money spent on acquisitions is larger than the gross domestic products (GDPs) of most countries. As a result of globalization and more liberal policies, we see more international acquisitions (IA), which constitute a significant portion of all foreign direct investment (FDI) activity around the world. IAs are one of the main vehicles for the internationalization of multinational companies (MNCs). Although Greenfield investment still accounts for more than half of all FDI flow, the number and value of IAs have been increasing faster than Greenfield investment (UNCTAD, 2012).

A large body of literature on the topic of acquisitions has developed in the fields of finance, management, economics, and accounting, which reflects the multidisciplinary nature of acquisitions. In the light of their popularity, acquisitions were found to provide a mixed performance for acquirers (Cartwright and Schoenberg, 2006). Despite the huge number of studies in this field, the failure rates were found to be the same, and the real impacts of acquisitions and the underlying success factors remain poorly understood (Rotting, 2009). Moreover, the question of why companies continue to use them, given the high failure rates, has still not been fully answered. These might explain the increasing number of studies published in acquisition research including the review studies. However, most of the reviews about acquisition research focus on domestic acquisitions (DA) or take a general approach of acquisitions (e.g., Haleblian, Devers, McNamara, Carpenter, and Davison, 2009; Cartwright and Schoenberg, 2006; 
Yönetim ve Ekonomi Araștırmaları Dergisi / Journal of Management and Economics Research

Cilt/Volume: $14 \quad$ Sayı/Issue: $4 \quad$ Eylül/September $2016 \quad$ Doi: http://dx.doi.org/10.11611/yead.282052

Shimizu, Hitt, Vaidyanath, and Pisano, 2004). Despite the increasing popularity of IAs, there is not a recent literature about how IAs are different from DAs. The goal of this study is to review the current state of literature on IAs and provide a review about the differences between international and domestic acquisitions, which has not been done in earlier review studies. Building on this review, we will also outline new directions for future acquisition research.

There are several differences between international and domestic acquisitions. IAs can be initiated with different motivations such as stock market return or fluctuations in currency of a foreign country, which are not antecedents for DAs. Agency costs are also more explicit in IAs compared to DAs, and they play a more triggering role for IAs. One of the major differences between IAs and DAs are in terms of success factors. Different from DAs, country factors such as cultural distance, institutions, etc. play a critical role in the success of IAs. The differences between the environments of acquirer and target in IAs make the post-acquisition integration process more complex compared to DAs. Moreover, those differences make the information asymmetry a bigger problem for IAs than for DAs. IAs also differ from DAs in terms of outcomes and they usually lead to lower performance than DAs. This has been attributed to the additional complexity of IAs, post-acquisition integration problems, information asymmetry, and agency costs. Despite these negative aspects of IAs, they provide diversification benefits which are not available for DAs. Finally, the issues in acquisitions research are identified and directions for future research are provided. Motivation-outcome inconsistency is a major problem in acquisition research and we suggest using multiple measures for assessing outcomes or survey studies to understand motivations better. These can also resolve the acquisition paradox, which still remains as an unanswered question. In terms of the directions for future research, there is a great potential in acquisitions by emerging markets or private firms and acquisition of state-owned enterprises, which have not been studied much. We also identify some topics that have great potential such pre-announcement and negotiation processes, target selection, due diligence, etc.

This study contributes to the literature in several ways. First of all, the increase in the number of studies published on this issue has provided new findings that could change the dynamics of this stream of literature. This review includes the most recent studies in IA research and provides new insights in the field. Another major contribution of this study is to focus on IAs. Most importantly, unlike earlier reviews, this review addresses differences between international and domestic acquisitions. This analysis also addresses some issues in acquisition research and propose ways to resolve them. Finally, understudied and novel areas in IA research were identified; this opened the door to new ways of studying IAs. 
Yönetim ve Ekonomi Araștırmaları Dergisi / Journal of Management and Economics Research

Cilt/Volume: $14 \quad$ Sayı/Issue: $4 \quad$ Eylül/September $2016 \quad$ Doi: http://dx.doi.org/10.11611/yead.282052

The rest of the paper proceeds as follows. In the next section, we provide an in-depth review about the differences between international and domestic acquisitions. The topics include the motivational differences, success factors, integration, information asymmetry, diversification, and outcomes. Next, we identify gaps in the acquisition research and provide future directions. In the last section, we conclude the review.

\section{DIFFERENCES BETWEEN INTERNATIONAL AND DOMESTIC ACQUISITIONS}

Acquisitions have received much attention in the literature, and there have been many reviews concerning them. In one of those studies, Shimizu, Hitt, Vaidyanath, and Pisano (2004) reviewed international acquisitions as a mode of entry, a dynamic learning process, and a value-creating strategy. Cartwright and Schoenberg (2006), based on the literature, discussed the reasons for the high failure rate of acquisitions. Some reviews specialize on particular aspects of acquisitions. For instance, Rotting (2009) examined international acquisitions from the perspective of the management field. Haleblian et al. (2009) developed a framework for examining studies about acquisitions in terms of antecedents, moderators, and outcomes. In another review study, Shi, Sun and Prescott (2011) combined the bodies of literature on alliance and acquisition and assessed them together. In his review of acquisitions, Vazirani (2012) assessed the performance outcomes of acquisitions from the human resource perspective. Another review study proposes linking existing approaches within acquisitions in order to acquire a better understanding of them (Gomes, Angwin, Weber, and Tarba 2013). The most recent review provides abibliometric study about mergers and acquisitions based on studies in the last 30 years (Ferreira, Santos, de Almeida, and Reis 2014). Most of these prior literature reviews addressing acquisitions focus on domestic acquisitions. However, an increasingly important portion of the acquisition activity in the world is occurring between different countries. Despite many similarities between international and domestic acquisitions, they cannot be treated the same. Therefore, it is important to make a distinction between domestic and international acquisitions and discuss the differences between them. In this study, we discuss the differences between international and domestic acquisitions based on the literature in this field.

\subsection{Motivational differences}

Firms engage in acquisitions at the optimal time: when the target is undervalued or the acquirer is overvalued. The valuation driver of an acquisition can be the result of market valuation or exchange rates. Country level differences play a critical role for IAs in terms of valuation driver of acquisitions. Companies that are located in countries whose stock markets have increased in value tend to engage in 
Yönetim ve Ekonomi Araștırmaları Dergisi / Journal of Management and Economics Research

Cilt/Volume: $14 \quad$ Sayı/Issue: $4 \quad$ Eylül/September $2016 \quad$ Doi: http://dx.doi.org/10.11611/yead.282052

more IAs (Erel, Liao, and Weisbach, 2012). The driver can be undervaluation of a foreign stock market as well.

Another view that has been used mainly in the finance literature to explain the valuation motivation of IAs is financial theory, which argues that companies take advantage of changes in the exchange rates when making IAs. When the currency of the country where the acquirer is located appreciates, targets in foreign countries become cheaper, and acquirers take advantage of undervalued targets.Uddin and Boateng (2011) found that exchange rates have a significant impact on IAs undertaken by UK companies.Georgopoulos (2008) provided similar empirical evidence for US acquisitions in Canada. Erel, et al., (2012) also showed that there are more acquisitions by firms whose country's currency has appreciated. In sum, market performance and currency fluctuations of foreign countries are important as drivers of IAs, which is not the case for DAs.

The agency view, which argues that the CEOs may not behave according to shareholders' interests, has also been used to explain the acquisition behavior of firms (Jensen, 1986; Shleifer and Vishny, 1989). This view posits that there is a conflict of interest between shareholders and managers, which leads to ego-driven acquisitions by managers. According to this view, managers engage in acquisitions for their own interests, which are not necessarily beneficial for the company. Increasing his or her compensation is one of the motivations for a CEO to undertake an acquisition. A breadth of literature has demonstrated that there is an increase in CEO compensation following an acquisition (Yim, 2013; Harford and Li, 2007; Grinstein and Hribar, 2004; Bliss and Rosen, 2001). In addition to increasing compensation, prior research has shown that CEOs tend to use acquisitions to build business empires, increase their power, and reduce employment risk (Gomez-Mejia and Wiseman, 1997; Haleblian and Finkelstein, 1993). As a result of increasing power, entrenched managers choose low-synergy targets and overpay, which leads to failures in acquisitions. (Harford, Humphery-Jenner and Powell, 2012). As IAs are larger than DAs on average, they have greater likelihood of being initiated with agency driven motivations compared to DAs. IAs lead to larger increases in firm size and hence more increase in CEO compensation. International acquisitions also increase the complexity of firms due to cultural differences, information asymmetry, geographic dispersion, and exchange rates (Duru and Reeb 2002). To the extent that complexity requires greater pay (Rosen, 1992), it follows that the CEO compensation should be greater following IAs than with domestic acquisitions. Therefore, the agency costs for IAs are greater than the costs for DAs. Because, CEOs can benefit from IAs more compared to DAs.

IAs are perceived to be riskier than DAs and there are also firm-level antecedents that affect the likelihood of IAs and DAs differently. For instance, greater slack and acquisition experience increase the 
Yönetim ve Ekonomi Araștırmaları Dergisi / Journal of Management and Economics Research

Cilt/Volume: $14 \quad$ Sayı/Issue: $4 \quad$ Eylül/September $2016 \quad$ Doi: http://dx.doi.org/10.11611/yead.282052

likelihood of engaging in an IA compared to a DA (Alessandri, Cerrato, and Depperu, 2014). CEO level factors also affect the likelihood of engaging in an IA rather than DA. A CEO might avoid risky but high potential IAs, which is not in the best interest of shareholders. Consistent with this argument, Matta and Beamish (2008) found that CEOs who have more options and equity in the company have less incentive to engage in IAs, in order to protect their own wealth. So, there are several motivations/drivers of acquisitions that have different impact on likelihood of international and domestic acquisitions.

\subsection{Success factors}

One of the major differences between IAs and DAs is the success factors. Unlike domestic acquisitions, IAs involve country-level factors that affect their success. Targets in IAs are from foreign markets, and there are country level differences in addition to firm level differences. These country-level factors have mainly been examined in the international business literature. The focal issue in this literature is the compatibility of institutions between home and host countries. For instance, cultural distance, which can be defined as a lack of cultur, al fit between countries, is one of the most-studied phenomena (e.g. Chakrabarti,Gupta-Mukherjee, andJayaraman, 2009; Reus and Lamont, 2009; Morosini, Shane, and Singh, 1998). Geographic distance, another country-level fctor, influences the communication and integration processes of acquisitions and has a negative impact on IA success (Kang and Kim, 2008).

Additional country-level factors that influence the success of IAs are laws and regulations in the host country. As common law tradition has a stronger orientation to the protection of private property rights, it provides better investor protection compared to the civil law tradition. Consistent with this view, Von Eije and Wiegerinck (2010) found greater bidder returns after acquisitions by common law firms compared to the acquisitions by civil law firms. Other examples of country-level factors that affect the success of IAs are investor protection (John, Freund, Nguyen and Vasudevan, 2010) and overall institutional quality (Brockman, Rui, and Zou, 2013).

\subsection{Post-acquisition integration}

Post-acquisition integration has been viewed as a challenge for acquisitions. Integration has been defined as the fit between the organizational cultures of the acquirer and the target, namely, the similarity of cultural practices, administrative procedures, and personal characteristics between the two firms (Jemison and Sitkin, 1986). This stream of literature, known as the process perspective, views integration of acquirer and target as a determinant of success or failure in acquisitions (Haspeslagh and Jemison, 1991; Kitching, 1967). According to this view, a lack of organizational fit leads to a culture clash between the acquirer and the target (Cartwright and Cooper, 1990). The underlying assumption of this view is that 
Yönetim ve Ekonomi Araștırmaları Dergisi / Journal of Management and Economics Research

Cilt/Volume: $14 \quad$ Sayı/Issue: $4 \quad$ Eylül/September $2016 \quad$ Doi: http://dx.doi.org/10.11611/yead.282052

large cultural differences could be correlated with negative emotional and behavioral responses of employees due to culture shock (Buono, Bowditch, and Lewis, 1985).

IAs differ from domestic acquisitions in terms of post-acquisition integration problems (Child, Falkner, and Pitkethly, 2001). The integration of two companies is a very complex process that is difficult to manage. Because the acquirer and the target in an IA are from different environments, complexities and problems in IAs are greater than in domestic acquisitions (Mukherji, Mukherji, Dibrell, and Francis, 2013). For instance, people from different cultures who speak different languages must work together after an IA, and their differences make it more difficult to manage the integration successfully. Employees at acquired company are less involved in the integration process and less cooperative when the cultural distance is great (Krug and Nigh, 2001). Cultural distance also impedes the transfer of key capabilities and constrains communication between the workforces of the acquirer and the target (Reus and Lamont, 2009). Lack of communication can lead to employee stress and negative attitudes during integration (Weber, Shenkar, and Raveh, 1996). Work alienation between individuals from the acquirers and the targets in IAs negatively affect technology and knowledge sharing as well (Brannen and Peterson, 2009). In addition, IAs have significantly more geographic distance when compared to domestic acquisitions. Geographic distance has been shown to negatively affect communications between the acquirer and target companies, which damages potential synergies (Kang and Kim, 2008). All these findings suggest that there are greater integration problems in IAs compared to DAs.

IAs pose additional challenges in terms of controlling and monitoring the acquired company, compared to DAs, even after the integration issues are resolved. For instance, accounting standards in the host country can prevent the acquirer from conducting effective monitoring. Personal behavioral differences due to national culture also affect controlling negatively in terms of impairing the motivation of employees of the acquired company.Being acquired by a foreign company can increase this insecurity more in an IA than in a domestic acquisition.

\subsection{Information asymmetry}

Information asymmetry is another area where IAs differ from domestic acquisitions. Information asymmetry between the acquirer and the target has been viewed as a major problem in acquisitions and a reason for failure. The basic notion behind this view is that the target firm possesses superior information about its own value, which makes it difficult for the acquirer to value the target (Akerlof, 1970). This creates a risk of overpayment for the acquirer, in addition to excessive costs during the due diligence and negotiation processes (Reuer, Shenkar,andRagozzino, 2004).Thus, information asymmetry leads to 
Yönetim ve Ekonomi Araștırmaları Dergisi / Journal of Management and Economics Research

Cilt/Volume: $14 \quad$ Sayı/Issue: $4 \quad$ Eylül/September $2016 \quad$ Doi: http://dx.doi.org/10.11611/yead.282052

overpayment or overvaluation of the target, which results with lower performance after an acquisition (Lin, Chou, and Cheng, 2011).

IAs pose greater risks than DAs in terms of information asymmetry. This is because, in an IA, there are more differences between two companies operating in different environments than in a DA (Mukherji et al., 2013). If the institutions are not well developed in the host country, the information asymmetry problem will be higher. For instance, the differences in accounting practices and disclosure requirements in the host country can prevent the acquirer from obtaining accurate information about the target. Information asymmetry regarding the intellectual assets of the target and the legal protection of these assets also creates uncertainty about the returns generated after an IA. This uncertainty lowers the synergy potential of an IA and leads to lower returns (Moeller and Schlingemann, 2005).

\subsection{Outcomes}

Although there are not many studies that compare international and domestic acquisitions in terms of outcomes, IAs are found to experience lower announcement stock returns compared to DAs (Conn, Cosh, Guest, and Hughes, 2005; Moeller and Schlingemann, 2005). Similarly, Weche Geluebcke (2015) found a negative effect of IAs on productivity compared to DAs in Germany. The market views IAs more negatively than domestic acquisitions because of international risks such as currency risk, political risk, and foreign market risk (Conn et al., 2005; Moeller and Schlingemann, 2005). In contrast with those studies, Bertrand and Zitouna (2008) found stronger efficiency gains for IAs compared toDAs. However, domestic acquisitions outperform international acquisitions in general.

There are several explanations for the performance differences between international and domestic acquisitions. Most of the negative aspects of acquisitions are more explicit in IAs than in domestic acquisitions, which affect their potential for success. For example, according to the agency theory, CEOs use acquisitions for their own interests at the expense of shareholders' interests. Because IAs are larger and more complex than domestic acquisitions (Mukherji et al., 2013), they create greater agency costs. Additionally, IAs differ from domestic acquisitions due to the complexities of operating in a new environment as well. This new environment elicits novel risks; for instance, firms that engage in IAs are faced with risks such as the "liability of foreignness" (Zaheer, 1995). As stated in earlier sections, IAs pose more challenges than DAs in terms of post-acquisition integration and information asymmetry as well, which may lead to lower performance.

IAs also have indirect effects, which are different from DAs. IAs are more complex than DAs, and management needs to put more effort into the integration process. Devoting too much time and effort to 
Yönetim ve Ekonomi Araștırmaları Dergisi / Journal of Management and Economics Research

Cilt/Volume: $14 \quad$ Sayı/Issue: $4 \quad$ Eylül/September $2016 \quad$ Doi: http://dx.doi.org/10.11611/yead.282052

the integration process may make top management unable to focus on other important decisions and may damage the overall performance of the company (Zollo and Meier, 2008). In some other cases, the expected synergies may be achieved, but the performance of the acquirer may not be improved due to the negative effects of acquisition on other stakeholders such as suppliers, government, competitors, customers, etc. (Zollo and Meier, 2008). For instance, a company may face informal sanctions by local government after an IA if the local competitors have power over the government. Acquirers restructure the target companies following the IAs, which can create some tension with the government and also result with a negative public image in the host country. These indirect negative outcomes are less of an issue for DAs where there is a more stable and certain environment.

\subsection{Diversification}

One of the differences between international and domestic acquisitions that favor IAs is the diversification. Boateng, Qian, and Tianle (2008) showed that the diversification is one of the main motivations of IAs.Companies want to diversify their earnings via IAs, and geographic diversificationhas shown to affect performance positively (Ramı'rez-Aleso`n and Espitia-Escuer, 2001). Companies which diversify through IAs can get a competitive advantage relative to companies who engaged in domestic acquisitions.

IAs also provide benefits in terms of location-specific advantages that are not available to domestic acquirers. For example, IAs can be more beneficial than DAs, as they allow acquirers to have access to the factor endowments in host countries, which in turn enhances productivity more compared to DAs (Conyon, Girma, Thompson, and Wright, 2002). IAs can also have benefits in terms of flexibility in dispersing production activities. Because the company has the option to locate production somewhere else, an IA gives it more bargaining power with employees. Lommerud, Straume, and Sogard (2006) showed that wages are lower after an IA than a DA. So, diversification provides additional benefits in IAs in terms of risk reduction and flexibility.

\section{NEW DIRECTIONS FOR ACQUISITION RESEARCH}

Although numerous acquisition studies have been accomplished, there are still many unanswered questions and gaps in the research. The present study proposes ways of completing acquisition research that will solve the discrepancies and understudied areas of prior research.

\subsection{Motivation / outcome inconsistency}

Companies engage in acquisitions for various reasons; enhancing innovativeness, improving their value by creating synergies, accessing important resources, improving productivity, preventing 
Yönetim ve Ekonomi Araștırmaları Dergisi / Journal of Management and Economics Research

Cilt/Volume: $14 \quad$ Sayı/Issue: $4 \quad$ Eylül/September $2016 \quad$ Doi: http://dx.doi.org/10.11611/yead.282052

competitors from becoming stronger, diversification, etc. On the other hand, most of the studies in the literature examine acquisition outcomes in terms of single performance measures, and most of them indicate high failure rates for acquisitions. However, companies have different motivations for acquisitions, and some of these motivations may not be covered by the measures used. For instance, a motivation for engaging in an acquisition could be improving productivity and efficiency, which may not be reflected in stock prices in the short term. Samples that are used for empirical studies contain acquirers with different motivations, but one dimension of performance is used to decide whether an acquisition is a success or failure, which creates the problem of motivation/outcome inconsistency. Consistent with this argument, Seth, Song, and Pettit (2002) suggested that a possible explanation for the conflicting findings in the literature might be a failure to account for the different motives of each acquisition. This is a more important problem in terms of international vs. domestic acquisitions. As stated earlier, the motivations of international and domestic acquisitions can be different and they cannot be treated the same.

We believe that the problem of motivation/outcome inconsistency can be addressed by developing new ways of assessing acquisition outcomes. Looking to one measure is not enough to determine whether an acquisition is a failure or not, because no single measure can cover different motivations. A significant number of studies have used short-term stock market reactions to acquisitions to assess their outcomes, following the basic principles that markets are efficient and that stock prices contain all of the pertinent information about the firms (Fama, 1970; MacKinlay, 1997). However, there is a growing body of literature (Fama and French, 2007; Zajac and Westphal, 2004) that argues that markets are not perfectly efficient all the times. Moreover, acquisitions are strategic actions by firms and contain different motivations. Due to the complexity of these events, it may be misleading to assume that the potential benefits and consequences of acquisitions are reflected in stock prices. There is empirical evidence about the inconsistency between short-term market reaction to acquisitions and returns in the long-term (e.g. Chang and Tsai, 2013; Oler, Harrison, and Allen, 2008). This empirical evidence shows that the shortterm reactions of markets might not assess the impacts of acquisitions appropriately; they can best indicate the expectations of the market for the acquisition, rather than the actual value created (Haleblian et al., 2009). Schijven and Hitt (2012) also proved that investors react to acquisitions based on the premiums paid and available public information instead of on objective, rational-deductive assessments. Profitability ratios have been criticized as assessing past performance but not providing insights about sustainable, long-term, competitive advantage (Buckley, Pass, and Prescott, 1988). They may also be misleading, as firms can forego short-term profits for long-term growth (Buckley et al., 1988), which is the case for many acquisitions. Similarly, Custodio (2014) demonstrates how the q-based measures, which are used 
Yönetim ve Ekonomi Araștırmaları Dergisi / Journal of Management and Economics Research

Cilt/Volume: $14 \quad$ Sayı/Issue: $4 \quad$ Eylül/September $2016 \quad$ Doi: http://dx.doi.org/10.11611/yead.282052

extensively to assess acquisition success, are biased. She argues that the acquired assets are usually reported higher than the actual pre-acquisition book values, which make the post-acquisition q-measures lower. She views this as a reason of the diversification discount and suggests subtracting goodwill from the book value of assets to calculate q-based measures. We suggest that acquisitions need to be elaborated beyond a single performance dimension, as they have implications for different outcomes.

Another way to address this problem and to link the motivations of companies to the outcomes of acquisitions is to use an index that consists of various performance measures. In this way, most of the motivations of companies will be taken into account, and the outcomes of acquisitions will be assessed more effectively. Creating an index also has its own challenges, such as which measures to use and what weight should be given to each measure. However, this is an area with great potential for acquisition research.

\subsection{The acquisition paradox}

Despite the high failure rates reported in the literature, acquisitions have been used extensively by companies; this discrepancy creates a paradox. Why do companies continue to engage in acquisitions at an increasing rate, given the high failure rates in the literature? There has been a pressing need to respond to this research lacuna. CEO overconfidence, agency costs, and managerial hubris have been widely used in the finance literature to explain this paradox (e.g., Billet and Qian, 2008; Ismail, 2008). However, increasing public information, which prevents opportunistic behavior, greater incentives for CEOs, and more effective monitoring by boards make these explanations puzzling. Because, all stated changes lower agency problems and the likelihood of opportunistic behavior of CEOs. Therefore, this discrepancy has not been resolved completely, and the question of why companies continue to use acquisitions remains unanswered.

One way to resolve this discrepancy is to understand the motivations of acquisitions better. Most of the identified motivations/antecedents of acquisitions depend on interpretations of data, but we do not know the real motivations of managers for acquisitions. Therefore, we need a better understanding of the motivations for acquisitions, which will lead us to assess outcomes more accurately. The best way to assess these motivations is to use survey methodology. However, due to the difficulty of collecting survey data from decision-makers, very few studies use this methodology in acquisition research (e.g., Zollo and Meier, 2008; Zaheer, Castaner, and Souder, 2013). This is an understudied area with great potential for future research. 
Yönetim ve Ekonomi Araștırmaları Dergisi / Journal of Management and Economics Research

Cilt/Volume: $14 \quad$ Sayı/Issue: $4 \quad$ Eylül/September $2016 \quad$ Doi: http://dx.doi.org/10.11611/yead.282052

Another novel perspective for addressing the issue of the acquisition paradox is to use riskadjusted returns to assess the outcomes of acquisitions. The expected rate of return is adjusted according to the level of risk in order to assess the attractiveness of an investment decision. Although there are huge variations in the risk levels of acquisitions, most studies have not taken risk into consideration and have focused only on outcomes. However, outcomes should be adjusted based on the amount of risk, and people should expect more returns with higher risk. Risk-adjusted returns should be used in order to assess and compare outcomes more effectively.

One of the underlying reasons for the acquisition paradox is the ambiguity of the definition of failure, as discussed earlier. The determination of an acquisition as a failure or success is closely related to the methodology used, which might be another way to explain the acquisition paradox. Most of studies have compared pre- and post-acquisition performance or have examined the post-acquisition performance alone to gauge the impacts of acquisitions. Although they are used frequently, these approaches have some drawbacks. They do not enable us to see what would happen to either firm if they did not engage in an acquisition. Despite econometric methods, there is no best way to determine whether a firm would perform better if it had not engaged in an acquisition. The best way to examine the impact would be to compare the performance of the company after engaging in an acquisition with its performance given no acquisition. To assess the effects of the acquisition, benchmarking can be used. The propensity score method, which is becoming increasingly popular (e.g. Brockman et al., 2013; Chang, Chung, and Jungbien Moon, 2013), is an effective way of comparing two samples to assess the impact of an event. Using a control sample enables us to exclude external factors that affect the performance of a company and assess the acquisition outcome more effectively. Thus, matching methodology should be used to assess acquisition outcomes effectively.

\subsection{New trends and understudied areas}

In this section, trends in acquisition are discussed, as they provide us with directions for future research. One of the trends is the increasing number of IAs compared to DAs as a result of globalization and global competition. According to the World Investment Report(UNCTAD, 2008) the value of IA activity in 2007 was $\$ 1,637$ billion and the IA activity has been increasing faster than Greenfield investment (UNCTAD, 2012). Due to the increasing number and growing importance for MNCs and their unique characteristics that differ them from domestic acquisitions, there is a need for a better understanding of the opportunities and challenges of IAs. One of the areas that have potential in IA research is governance in the host country. We still do not know which governance dimensions are most important in explaining the IA performance. There are also relatively few studies about the impact of 
Yönetim ve Ekonomi Araștırmaları Dergisi / Journal of Management and Economics Research

Cilt/Volume: $14 \quad$ Sayı/Issue: $4 \quad$ Eylül/September $2016 \quad$ Doi: http://dx.doi.org/10.11611/yead.282052

different stakeholders on IA success. In one of these studies, Fong, Lee, and Du (2013) found that Chinese consumers exhibit attitudes that are more negative toward the post-acquisition target following an acquisition by foreigners. We believe that stakeholders in the host country, such as non-governmental organizations, banks, and local suppliers are worth examining in terms of their impact on IAs.

Another pattern regarding acquisition activity is the increase in involvement of MNCs from emerging markets. Most acquisitions used to occur between developed countries. However, the percentage of acquisitions that involve emerging countries increased from $10 \%$ to $30 \%$ in last ten years (The Economist, 2010), whereas in 2010, the share of European countries fell to 29\% (Saigol and Thomas, 2010). Most of the findings in the literature are based on public US or European acquirers. However, emerging firm acquirers have different characteristics, and the results of prior studies cannot be generalized to them. There is empirical evidence regarding the variations in returns based on different sampling techniques (e.g.Capron and Shen, 2007). There are also very few studies that examine the private acquirers, which can have different characteristics than public firms. In one of the few studies that examine private acquirers, Bargeron,Schlingemann, Stulz, and Zutter (2008) showed why public acquirers pay more premiums compared to private acquirers. Given the greater availability of data on emerging markets and private firms, future acquisition studies should focus more on acquirers from emerging countries and on acquisitions undertaken by private firms. Moreover, given the trend of privatization in emerging and developing countries, MNCs have been increasingly acquiring state-owns enterprises. There are very few studies that examine the acquisitions of state-owned enterprises (e.g. Jory and Ngo, 2014), which is an understudied area.

Most of the literature has examined the antecedents and outcomes of acquisitions. Antecedents are related to the period before the acquisition announcement, and outcomes are related to the period after the deal is completed. There is a period between the acquisition announcement and completion when a significant amount of negotiation is taking place. Almost $20 \%$ of announced acquisitions are withdrawn during this period. However, we do not know much about what is happening during this time. The reasons for withdrawn acquisition announcements and the impact of these on both the acquirer and target are necessary research areas. In one of the very few studies that examine withdrawn acquisitions, Jacobsen (2014) show that market reacts more positively to the withdrawal decisions related to price compared to withdrawal decisions for other reasons. The pre-announcement period is also an understudied area and there are very few studies about this period. In one of these studies, Luypaert and De Maeseneire (2015) examined the drivers of deal completion and completion time. Selecting the right target is crucial for 
Yönetim ve Ekonomi Araștırmaları Dergisi / Journal of Management and Economics Research

Cilt/Volume: $14 \quad$ Sayı/Issue: 4 Eylül/September $2016 \quad$ Doi: http://dx.doi.org/10.11611/vead.282052

creating synergies and an effective integration process. The target selection process before the announcements should be examined in future studies to answer the following questions: How do acquirers select targets? What are the critical criteria that affect the selection of the right targets?

Acquisitionstudies usually examine a single acquisition and its impact on a company for a specific time period. However, acquisitions are usually a part of long-term organizational plans. Instead of taking a one-shot picture of a company, scholars should adopt a larger perspective and look at other acquisitions and strategies of the company. Barkema and Schijven (2008) stated that, "The performance implications of a single acquisition are dependent on that acquisition's position within the acquirers' acquisition sequence. Thus, accounting for post-acquisition integration as a long-term process rather than a 'one-shot game' can reveal acquirer gains that are often overlooked when examining single acquisition events." (Barkema and Schijven, 2008: 715). Following this notion, a series of acquisitions of firms can be analyzed in the future. The question of which acquisitions create more value in a sequence of acquisitions would be an interesting, future research topic.

\section{CONCLUSION}

Scholars from multiple fields, including management, finance, and economics have shown increasing interest in acquisitions. As indicated earlier, acquisition research is still incomplete, and there are a number of issues that need to be resolved. In this study, a review of acquisition research in terms of the differences between international and domestic deals, is provided. This study has contributed to the field of M\&As in several ways. First of all, to the best of our knowledge, there is not a literature review that compares international and domestic acquisitions. We fill this gap by reviewing studies and comparing international and domestic acquisitions. This study proves that the international and domestic acquisitions are not the same and they should be treated differently. There is a need for more studies that compare international and domestic acquisitions. This comparison can be done in terms of both motivations and outcomes of acquisitions. More importantly, the success factors of international and domestic acquisitions can be different as some factors can affect two types of acquisitions differently. Thus, international and domestic acquisitions should be compared in terms of success factors as well.

Our study also identifies the issues in acquisition research and provides some insights to resolve them. One of the major problems in M\&A research, the discrepancy between the findings and practitioners' behavior, is identified and referred as the acquisition paradox. Motivation/outcome inconsistency is discussed as another problem in previous studies. This review raises questions about the definition of failure for acquisitions and suggests new ways of assessing acquisition outcomes. This study 
Yönetim ve Ekonomi Araștırmaları Dergisi / Journal of Management and Economics Research

Cilt/Volume: $14 \quad$ Sayı/Issue: $4 \quad$ Eylül/September $2016 \quad$ Doi: http://dx.doi.org/10.11611/yead.282052

also draws attention to trends in acquisitions and show that IAs and acquisitions done by private firms and multinationals in emerging countries need more attention, due to their increasing use. Understudied areas, such as the pre-announcement period, the negotiation and due diligence processes, factors that affect acquisition completion and serial acquisitions were also identified. Despite these contributions, the study has some limitations. This study has not any empirical analyses to examine the findings eonomometrically. A meta-analyses about the findings of international and domestic comparisons will be a good future research oppurtunity. As most of the existing literatüre is based on the samples from developed countries, this literature is more applicable to developed country context. This limits the generalizability of findings to emerging country contexts. A literature-review focused on emerging markets acquuisitions can be another potential study for future research.

\section{REFERENCES}

Akerlof, G.A. (1970) "The Market for "Lemons": Quality Uncertainty and the Market Mechanism", Quarterly Journal of Economics,vol. 84, no. 3, pp. 488-500.

Alessandri, T., Cerrato, D. \& Depperu, D. (2014) "Organizational Slack, Experience, and Acquisition Behavior Across Varying Economic Environments", Management Decision, vol. 56, no. 5, pp. 967982.

Bargeron, L.L., Schlingemann, F.P., Stulz, R.M. \& Zutter, C.J. (2008) "Why Do Private Acquirers Pay So Little Compared to Public Acquirers?", Journal of Financial Economics, vol. 89, no. 3, pp. 375-390.

Barkema, H.G. \& Schijven, M. (2008) "Toward Unlocking the Full Potential of Acquisitions: the Role of Organizational Restructuring", Academy of Management Journal,vol. 51, no. 4, pp. 696-722.

Bertrand, O. \& Zitouna, H. (2008) "Domestic Versus Cross-Border Acquisitions: Which Impact on the Target Firms' Performance?", Applied Economics,vol. 40, no. 17, pp. 2221-2238.

Billet, M. \& Qian, Y. (2008) "Are Overconfident Managers Born or Made? Evidence of Self-Attribution Bias from Frequent Acquirers", Management Science,vol. 54, no. 6, pp. 1037-1051.

Bliss, R.T. \& Rosen, R.J. (2001) "CEO Compensation and Bank Mergers", Journal of Financial Economics, vol. 61, no. 1, pp. 107-138. 
Yönetim ve Ekonomi Araștırmaları Dergisi / Journal of Management and Economics Research

Cilt/Volume: $14 \quad$ Sayı/Issue: 4 Eylül/September $2016 \quad$ Doi: http://dx.doi.org/10.11611/yead.282052

Boateng, A., Qian, W. \& Tianle, Y. (2008) "Cross-border M\&As by Chinese Firms: An Analysis of Strategic Motives and Performance", Thunderbird International Business Review, vol. 50, no. 4, pp. 259-270.

Brannen, M.Y. \& Peterson, M.F. (2009) "Merging Without Alienating: Interventions Promoting CrossCultural Organizational İntegration and Their Limitations", Journal of International Business Studies, vol. 40, no. 3, pp. 468-489.

Brockman, P., Rui, O.M. \& Zou, H. (2013) "Institutions and the Performance of Politically Connected M\&As", Journal of International Business Studies,vol. 44, no. 8, pp. 833-852.

Buckley, P.J., Pass, C.L. \& Prescott, K. (1988) "Measures of International Competitiveness: A Critical Survey", Journal of Marketing Management, vol. 4, no. 2, pp. 175-200.

Buono, A.F., Bowditch, J.L. \& Lewis, J.W. (1985) "When Cultures Collide: The Anatomy of a Merger", Strategic Management Journal,vol. 38, no. 5, pp. 477 - 500.

Capron, L. \& Shen, J. (2007) "Acquisitions of Private vs. Public Firms: Private Information, Target Selection, and Acquirer Returns", Strategic Management Journal,vol. 28, no. 9, pp. 891-911.

Cartwright, S. \& Cooper, C.L. (1990) "The Impact of Mergers and Acquisitions on People at Work: Existing Research and Issues", British Journal of Management, vol. 1, no. 2, pp. 65-76.

Cartwright, S. \& Schoenberg, R. (2006) "Thirty Years of Mergers and Acquisitions Research: Recent Advances and Future Opportunities", British Journal of Management, vol. 17, pp. 1-5.

Chakrabarti, R., Gupta-Mukherjee, S. \& Jayaraman, N. (2009) "Mars-Venus Marriages: Culture and Cross-Border M\&A", Journal of International Business Studies, vol. 40, no. 2, pp. 216-236.

Chang, S., Chung, J. \& Jungbien Moon, J. (2013) "When Do Foreign Subsidiaries Outperform Local Firms?", Journal of International Business Studies, vol. 44, no. 8, pp. 853-860.

Chang, S. \& Tsai, M. (2013) "Long-run Performance of Mergers and Acquisition of Privately Held Targets: Evidence in the USA", Applied Economics Letters, vol. 20, no. 6, pp. 520-524. 
Yönetim ve Ekonomi Araștırmaları Dergisi / Journal of Management and Economics Research

Cilt/Volume: $14 \quad$ Sayı/Issue: $4 \quad$ Eylül/September $2016 \quad$ Doi: http://dx.doi.org/10.11611/yead.282052

Child, J., Falkner, D. \& Pitkethly, R. (2001) "The Management of International Acquisitions", Oxford Univ. Press, Oxford, UK.

Conn, R.L., Cosh, A., Guest, P.M. \& Hughes, A. (2005) "The Impact on UK Acquirers of Domestic, Cross-border, Public and Private Acquisitions", Journal of Business Finance \& Accounting,vol. 32, no. 5 , pp. $815-870$.

Conyon, M.J., Girma, S., Thompson, S. \& Wright, P.W. (2002) "The Productivity and Wage Effects of Foreign Acquisition in the United Kingdom", Journal of Industrial Economics, vol. 50, no. 1, pp. 85.

CUSTÓDIO, C. (2014) "Mergers and Acquisitions Accounting and the Diversification Discount", Journal of Finance, vol. 69, no. 1, pp. 219-240.

Duru, A. \& Reeb, D.M. (2002) "Geographic and Industrial Corporate Diversification: The Level and Structure of Executive Compensation", Journal of Accounting, Auditing \& Finance,vol. 17, no. 1, pp. $1-24$.

Erel, I., Liao, R. C., \& Weisbach, M. S. (2012) "Determinants of Cross-Border Mergers and Acquisitions", Journal of Finance, vol. 67, no. 3, pp. 1045-1082.

Fama, E.F. (1970) "Efficient Capital Markets: a Review of Theory and Empirical Work", Journal of Finance,vol. 25, no. 2, pp. 383-417.

Fama, E.F. \& French, K.R. (2007) "Disagreement, Tastes, and Asset Prices", Journal of Financial Economics,vol. 83, no. 3, pp. 667-689.

Ferreira, M.P., Santos, J.C., de Almeida, M. I. R.\& Reis, N.R. (2014) "Mergers \& acquisitions research: A bibliometric study of top strategy and international business journals, 1980-2010", Journal of Business Research, vol. 67, no. 12, pp. 2550-2558.

Fong, C., Lee, C. \& Du, Y. (2013) "Target reputation transferability, consumer animosity, and crossborder acquisition success: A comparison between China and Taiwan", International Business Review,vol. 22, no. 1, pp. 174-186. 
Yönetim ve Ekonomi Araștırmaları Dergisi / Journal of Management and Economics Research

Cilt/Volume: $14 \quad$ Sayı/Issue: $4 \quad$ Eylül/September $2016 \quad$ Doi: http://dx.doi.org/10.11611/yead.282052

Georgopoulos, G.J. (2008) "Cross-border mergers and acquisitions: does the exchange rate matter? Some evidence for Canada", Canadian Journal of Economics,vol. 41, no. 2, pp. 450-474.

Gomes, E., Angwin, D.N., Weber, Y. \& Tarba, S.Y. (2013) "Critical Success Factors through the Mergers and Acquisitions Process: Revealing Pre- and Post-M\&A Connections for Improved Performance", Thunderbird International Business Review, vol. 55, no. 1, pp. 13-35.

Gomez-Mejia, L. \& Wiseman, R.M. (1997) "Reframing Executive Compensation: An Assessment and Outlook", Journal of Management, vol. 23, no. 3, pp. 291.

Grinstein, Y. \& Hribar, P. (2004) "CEO compensation and incentives: Evidence from M\&A bonuses", Journal of Financial Economics, vol. 73, no. 1, pp. 119-143.

Haleblian, J., Devers, C.E., McNamara, G., Carpenter, M.A. \& Davison, R.B. (2009) "Taking Stock of What We Know About Mergers and Acquisitions:A Review and Research Agenda", Journal of Management,vol. 35, no. 3, pp. 469-502.

Haleblian, J. \& Finikelstein, S. (1993) "Top Management Team Size, CEO Dominance, and Firm Performance: the Moderating Roles of Environmental Turbulence and Discretion", Academy of Management Journal,vol. 36, no. 4, pp. 844-863.

Harford, J. \& Li, K. (2007) "Decoupling CEO Wealth and Firm Performance: The Case of Acquiring CEOs", Journal of Finance,vol. 62, no. 2, pp. 917-949.

Harford, J., Humphery-Jenner, M. \& Powell, R. (2012) "The sources of value destruction in acquisitions by entrenched managers", Journal of Financial Economics, vol. 106, no. 2, pp. 247-261.

Haspeslagh, P.C. \& Jemison, D.B. (1991) "Managing acquisitions: Creating value through corporate renewal",New York, The Free Press.

Ismail, A. (2008) "Which acquirers gain more, single or multiple? Recent evidence from the USA market", Global Finance Journal, vol. 19, no. 1, pp. 72-84.

Jacobsen, S. (2014) "The death of the deal: Are withdrawn acquisition deals informative of CEO quality?", Journal of Financial Economics, vol. 114, no. 1, pp. 54-83. 
Yönetim ve Ekonomi Araștırmaları Dergisi / Journal of Management and Economics Research

Cilt/Volume: $14 \quad$ Sayı/Issue: $4 \quad$ Eylül/September $2016 \quad$ Doi: http://dx.doi.org/10.11611/yead.282052

Jemison, D.B. \& Sitkin, S.B. (1986) "Corporate Acquisitions: A Process Perspective", Academy of Management Review, vol. 11, no. 1, pp. 145-163.

Jensen, M.C. (1986) "Agency Costs of Free Cash Flow, Corporate Finance, and Takeovers", American Economic Review,vol. 76, no. 2, pp. 323.

John, K., Freund, S., Nguyen, D. \& Vasudevan, G.K. (2010) "Investor protection and cross-border acquisitions of private and public targets", Journal of Corporate Finance, vol. 16, no. 3, pp. 259-275.

Jory, S.R. \& Ngo, T.N. (2014) "Cross-border acquisitions of state-owned enterprises", Journal of International Business Studies,vol. 45, no. 9, pp. 1096-1114.

Kang, J. \& Kim, J. (2008) "The Geography of Block Acquisitions", Journal of Finance, vol. 63, no. 6, pp. 2817-2858.

Kitching, J. (1967) "Why do mergers miscarry?", Harvard Business Review, vol. 45, no. 6, pp. 84-101.

Krug, J.A. \& Nigh, D. (2001) "Executive Perceptions in Foreign and Domestic Acquisitions: An Analysis of Foreign Ownership and its Effect on Executive Fate", Journal of World Business,vol. 36, no. 1, pp. 85 .

Lin, H., Chou, T. \& Cheng, J. (2011) "Does market misvaluation drive post-acquisition underperformance in stock deals?", International Review of Economics \& Finance, vol. 20, no. 4, pp. 690-706.

Lommerud, K.E., Straume, O.R. \& Søgard, L. (2006) "National versus international mergers in unionized oligopoly", RAND Journal of Economics (RAND Journal of Economics), vol. 37, no. 1, pp. 212-233.

Luypaert, M. \& De Maeseneire, W. (2015) "Antecedents of time to completion in mergers and acquisitions", Applied Economics Letters, vol. 22, no. 4, pp. 299-304.

MacKinlay, A.C. (1997) "Event Studies in Economics and Finance", Journal of Economic Literature, vol. 35, no. 1, pp. 13-39.

Matta, E. \& Beamish, P.W. (2008) "The accentuated CEO career horizon problem: evidence from international acquisitions", Strategic Management Journal, vol. 29, no. 7, pp. 683-700. 
Yönetim ve Ekonomi Araștırmaları Dergisi / Journal of Management and Economics Research

Cilt/Volume: $14 \quad$ Sayı/Issue: $4 \quad$ Eylül/September $2016 \quad$ Doi: http://dx.doi.org/10.11611/yead.282052

Moeller, S.B. \& Schlingemann, F.P. (2005) "Global diversification and bidder gains: A comparison between cross-border and domestic acquisitions", Journal of Banking \& Finance, vol. 29, no. 3, pp. 533-564.

Morosini, P., Shane, S. \& Singh, H. (1998) "National Cultural Distance and Cross-Border Acquisition Performance", Journal of International Business Studies, vol. 29, no. 1, pp. 137-158.

Mukherji, A., Mukherji, J., Dibrell, C. \& Francis, J.D. (2013) "Overbidding in cross-border acquisitions: Misperceptions in assessing and valuing knowledge", Journal of World Business, vol. 48, no. 1, pp. $39-46$.

Oler, D.K., Harrison, J.S. \& Allen, M.R. (2008) "The danger of misinterpreting short-window event study findings in strategic management research: an empirical illustration using horizontal acquisitions", Strategic Organization, vol. 6, no. 2, pp. 151-184.

Ramírez-Alesón, M. \& Espitia-Escuer, M. (2001) "The Effect of International Diversification Strategy on the Performance of Spanish — Based Firms During the Period 1991-1995", Management International Review (MIR),vol. 41, no. 3, pp. 291-315.

Reuer, J.J., Shenkar, O. \& Ragozzino, R. (2004) "Mitigating risk in international mergers and acquisitions: the role of contingent payouts", Journal of International Business Studies, vol. 35, no. 1, pp. 19-32.

Reus, T.H. \& Lamont, B.T. (2009) "The double-edged sword of cultural distance in international acquisitions", Journal of International Business Studies,vol. 40, no. 8, pp. 1298-1316.

Rosen, R. (1992) "Contracts and the market for executives. In Wein, L., Wijker, H." in Contract Economics Cambridge, Mass.: Blackwell, pp. 181-211.

Rotting, D. (2009) "Research on International Acquisition Performance: a Critical Evaluation and New Directions", 2009 Academy of Management Annual Meeting Proceedings, pp. 1-6.

Saigol, L. \& Thomas, H. (2010) "Emerging markets M\&A outstrips Europe". The Financial Times, 2010, 20 September, 13 
Yönetim ve Ekonomi Araștırmaları Dergisi / Journal of Management and Economics Research

Cilt/Volume: $14 \quad$ Sayı/Issue: $4 \quad$ Eylül/September $2016 \quad$ Doi: http://dx.doi.org/10.11611/yead.282052

Schijven, M. \& Hitt, M.A. (2012) "The vicarious wisdom of crowds: toward a behavioral perspective on investor reactions to acquisition announcements", Strategic Management Journal, vol. 33, no. 11, pp. 1247-1268.

Seth, A., Song, K. \& Pettit, R. (2002) "Value creation and destruction in cross-border acquisitions: An empirical analysis of foreign acquisitions of US firms", Strategic Management Journal,vol. 23, no. 10, pp. 921-940.

Shi, W., Sun, J., \& Prescott, J. E. (2011). “A temporal perspective of merger and acquisition and strategic alliance initiatives: Review and future direction”,Journal of Management, vol. 38, no.1, pp. 164-209.

Shimizu, K., Hitt, M.A., Vaidyanath, D. \& Pisano, V. (2004) "Theoretical foundations of cross-border mergers and acquisitions: A review of current research and recommendations for the future", Journal of International Management,vol. 10, no. 3, pp. 307-353.

Shleifer, A. \& Vishny, R.W. (1989) "Management Entrenchment", Journal of Financial Economics,vol. 25, no. 1, pp. 123-139.

The Economist (2010) Global Mergers and Acquisitions, 3 July.

Uddin, M. \& Boateng, A. (2011) "Explaining the trends in the UK cross-border mergers \& acquisitions: An analysis of macro-economic factors", International Business Review,vol. 20, no. 5, pp. 547-556.

UN Conference on Trade and Development (UNCTAD) (2012) "World Investment Report: Towards a New Generation of Investment Policies", United Nations Publications, New York.

UN Conference on Trade and Development (UNCTAD) (2008) "World Investment Report: Transnational Corporations, and the Infrastructure Challenge", United Nations Publications, New York.

Vazirani, N. (2012) "Mergers and Acquisitions Performance Evaluation- A Literature Review", SIES Journal of Management, vol. 8, no. 2, pp. 37-42.

Von Eije, H. \& Wiegerinck, H. (2010) "Shareholders' reactions to announcements of acquisitions of private firms: Do target and bidder markets make a difference?", International Business Review,vol. 19 , no. 4, pp. 360-377. 
Yönetim ve Ekonomi Araștırmaları Dergisi / Journal of Management and Economics Research

Cilt/Volume: $14 \quad$ Sayı/Issue: 4 Ey/ül/September $2016 \quad$ Doi: http://dx.doi.org/10.11611/yead.282052

Weber, Y., Shenkar, O. \& Raveh, A. (1996) "National and corporate cultural fit in mergers/acquisitions: An exploratory study", Management Science, vol. 42, no. 8, pp. 1215-1227.

Weche Geluebcke, J.P. (2015) "The impact of foreign takeovers: comparative evidence from foreign and domestic acquisitions in Germany", Applied Economics, vol. 47, no. 8, pp. 739-755.

Yim, S. (2013) "The acquisitiveness of youth: CEO age and acquisition behavior", Journal of Financial Economics,vol. 108, no. 1, pp. 250-273.

Zaheer, A., Castaner, X. \& Souder, D. (2013) "Synergy Sources, Target Autonomy, and Integration in Acquisitions", Journal of Management, vol. 39, no. 3, pp. 604-632.

Zaheer, S. (1995) "Overcoming the Liability of Foreignness", Academy of Management Journal,vol. 38, no. 2, pp. 341-363.

Zajac, E.J. \& Westphal, J.D. (2004) "The Social Construction of Market Value: Institutionalization and Learning Perspectives on Stock Market Reactions", American Sociological Review, vol. 69, no. 3, pp. 433-457.

Zollo, M. \& Meier, D. (2008) "What Is M\&A Performance?", Academy of Management Perspectives, vol. 22 , no. 3 , pp. 55-77. 